\title{
ポリスチレンマイクロカプセル膜の小孔生成
}

\author{
野沢 䇌夫*1・東出 福司*1
}

(受付 1977 年 4 月 30 日・落查絡了 1977 年 7 月 15 日)

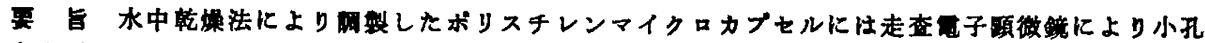

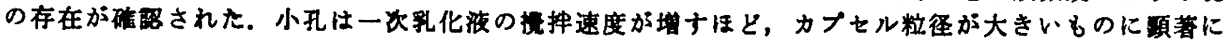

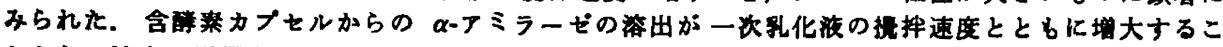

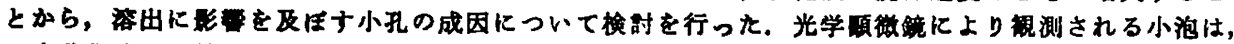

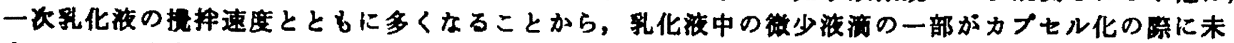

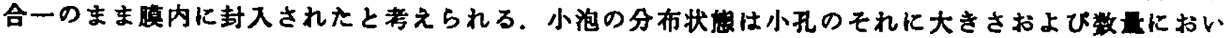

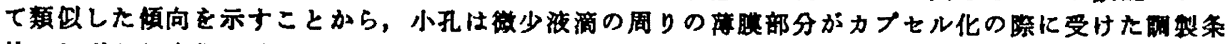
件のわずかな亲化で破れることにより生成したと解独される。
\end{abstract}

\section{1 棈}

マイクロカブセル(カブセル)はその特政的な大きさと 形状のゆえに実用的に興味ある物性を示すが，そのため 多くの研究者によりカブセル化とその応用に関する研究 が皘婳的に進められ，既にカブセル化に関して供れた総

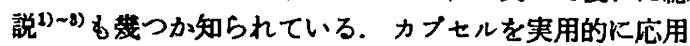
する場合，特に医薬品分野においては，膜の半透性を利 用したカブセルからの芯物質溶出の徐放性効果および容 出の $\mathrm{pH}$ 传存性など，主として膜の性筫に関係する場合

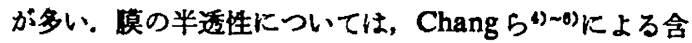
薬物カブセルの䠛床薬理学への応用に闺する一連の研究 て最初にその存在が指摘された，そしてさらに近藤n， 後藤㫙らにより，カブセル膜の膜透過性に関する定量的 な取扱いがなされた。膜の半透性は親水性高分子材料を 壁莫としたカブセルによく見いだされる9,100．しかし， 瑓水性膜材料から成る含水カブセルの場合でも，芯物質 容出挙動に類似性が見られることから，同棣に膜が半透 性を持つとする考え方で仼とんどが説明されだ1).

本中乾燥法によって調製されたボリスチレン(PS) カ ブセルにおいて，カブセル内醉秦の溶出が見られること から，膜に醭素が溶出するに十分な大きさの孔が存在す ることが推察された ${ }^{12)}$. さらに電子頭微䍌による観察か ら，明らかに膜に小孔が存在することが初めて見いださ

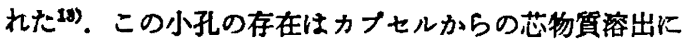
腸溶性および時限粒としての諸機能を賦与することがで きる可能性を示唆している点で意義深い(14).

*1 静岡菜科大学 ( 422 婙岡市小鹿 2-2-1)
本論文では，本中渂燥法を用いて得られるPS カブセ ルについて，芯物質溶出に重要な役割を担ら小孔の生成 機構に関して，カブセルからの芯物質溶出とカブセルの 顕微鏡による钼察結果をむとに検討を行った。

\section{2 実跧}

\section{1 カブセルの䑚畏}

カブセルの調製は水中䔛燥法により行った。 PS(市服 品)の $10 \%$ メチレンクロリド溶夜 4 部に対し, 釈化安 定㓱として用いたぜラチンの $8 \%$ を含む水溶液 1 部を加 えホモジナイザー(日本棈機 (株)製)でよく接找乳化さ せる. 含酻菜カブセルの場合は $0.6 \mathrm{~g} の \alpha$-フミラーゼ と $8 \%$ ぜラチンを含む程街液から調製した水客液を用い て乳化させた，これを W/O 型一次乳化液とする．看化

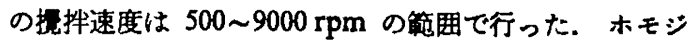
ナイザーには片刃のプロベラ型 6 枚羽が装着されてい る. 次にこの乳化液を $37^{\circ} \mathrm{C}$ の $2 \%$ ゼラチン水溶液 (300 rpm で港䢁) $600 \mathrm{ml}$ 中に注意深く注ぎ込み，約 4 時間以上にわたって溶剂桌がなくなるまで港拌を綂け る. この状態を $(\mathrm{W} / \mathrm{O}) / \mathrm{W}$ 型二次乳化液とする. 溶倣が 徐々に繁発するにつれ, 白色様のカブセルが本中に分散 し, 含水カブセルが生成する.これを直ちに流水にて十 分洗浄し，150，48，35 ィッシニのふるいを用い，粒径 $100 \sim 300 \mu \mathrm{m}, 300 \sim 400 \mu \mathrm{m}$ のカブセルに分級し捕集し た. カブセルの泌度は含水状態で $1.03 \sim 1.04 \mathrm{~g} / \mathrm{cm}^{8}$ で あった. カブセルの渂㺐は風乾により行った，カブセル は乾燥させても形状が変形することなく元の球状を保持 した. 本実検ではぜラチン以外の乳化安定骫は用いてな い. 


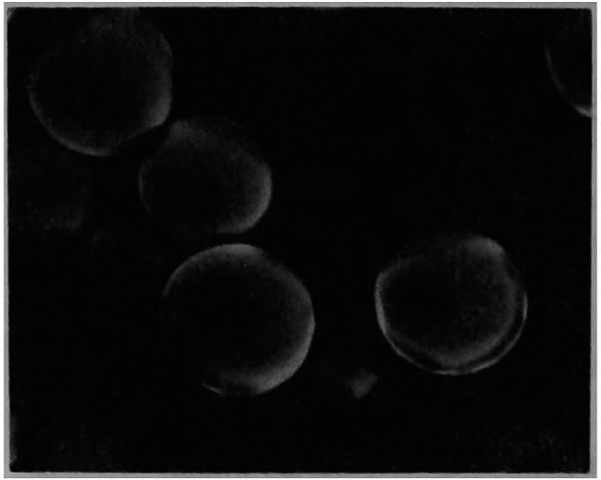

(a)

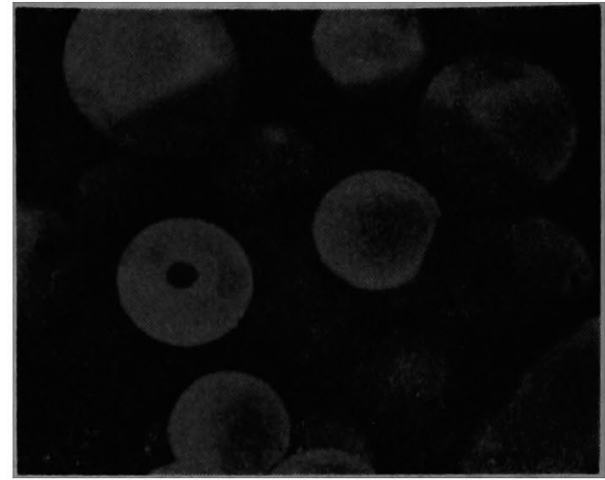

(b)

Fig. 1. Scanning electron micrographs of polystyrene capsules prepared from the emulsions agitated slowly $(500 \mathrm{rpm})$ : capsule size (a), $100-300 \mu \mathrm{m}$ diameter $(\times 300) ; \quad(b), \quad 300-400 \mu \mathrm{m}$ diameter $(\times 100)$.

\section{2 試犀の調製}

酵素は枯草菌 $\alpha-7$ ミラーゼ (20 単位 $/ \mathrm{mg}$ ，和光純薬 (侏) 製) を用い, $\alpha-$ ミラーゼの活性測定に用いたデン プンは市服の可容性デンプンを水ーメタノール系で 3 回 精製し風乾させた．緩衝夜は 0.2 モルのリン酸 2 水素カ リウムにカセインーダを加えて $\mathrm{pH} 5.8 \sim 6.0$ に調製し たものを用いた。 ヨウ素溶液は $2 \%$ ヨウ化カリウムと $0.2 \%$ のヨウ素を含む溶液として調製した。

\section{3 カプセルからの a-アミラーゼの溶出}

頡素カブセル $4 \mathrm{~g}$ (これは乾量で $0.75 \mathrm{~g}$ に相当する) を円筒形容器(底面に 150 メッシュのしんちゅう製金銅 を取り付けたすの) に入れ流水にて上く洗浄し，これを $37^{\circ} \mathrm{C}$ の $0.2 \%$ デンプン溶液 $240 \mathrm{ml}$ 中に入れて反応さ せ, 反応液を経時的に採取し，それぞれをヨウ素溶液に より発色させ，デンブンの分解挙動を Fuwa の方法 ${ }^{10)}$ に従って $700 \mathrm{~nm}$ における吸光度測定で追跡した。

\section{4 カプセルの顕微鏡写直}

光学顕徽鏡写真はオリンパス(株) 製 MF 型金属頭徽 鏡を用いて擢影した. カブセルの大きさは接眼マイクロ メーターを用いて湘定した，走査電子䫒徽鏡写真は日本 電子(株) 製 JSM-50A 型走查電子顕微鏡により，各種試 料カプセルにカーボン一金を蒸着させて撮影した。

\section{3 結果および考察}

\section{1 カプセル膜の多孔性と芯物賈溶出}

水中乾燥法により PS カプセルを調製する場合, カプ セル生成に及ぽす実験的因子は主として W/O 型一次乳 化液と $(\mathrm{W} / \mathrm{O}) / \mathrm{W}$ 型二次䄻化液に関係する条件である. 後者はカプセルの粒径とその分布に，そして前者はカプ 七ル膜の性質，すなわち膜厚および膜の均一性に関係す

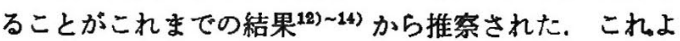

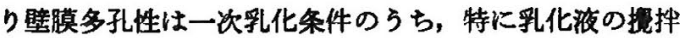
速度によってひき起こされるとして，走查電子顕徽鏡に よるカブセル膜の多孔性およびカブセルからの芯物質溶

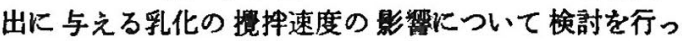
た.

走査電子䫒改鏡によるカブセル膜の小孔に関しては既 に報告したが18),14)，ここではさらに，摫拌速度 500 お よび $9000 \mathrm{rpm}$ で乳化した乳化液から調製したカブセル の $100 \sim 300 \mu \mathrm{m}$ および 300 400 $\mu \mathrm{m}$ に分級したものの 走査電子顕微鏡写真を Fig. 1 および 2 に示した. な お, Fig. 2-b の写真は第 3 回国際マイクロカブセルシン ポジウムで発表したものに類似するが，カブセル粒径に よる小孔の数の違いを分かりやすくするために並へて図 示した。乳化液の毗䢁速度が遅い場合，100 300 $\mu \mathrm{m}$ で の小粒径カブセルにおいては，その表面は視野の範围で 均一な膜状を呈し，完全な球体を示した。しかし 300〜 $400 \mu \mathrm{m}$ の大粒径カブセルでは幾つがれ孔の存在が認め られた. 特に大粒径カプセルほど多数の小孔が見られ， その大きさはおよそ 1 10 $\mu \mathrm{m}$ と概算された。これより 靦挥速度の增大とともに孔は小さくなるが，その数が增 大することから，カブセル膜の多孔性は乳化鯇挥速度に 直接関保することが推察された。

PS カブセルからの芯物質浴出についてはすでに詳し く検討されているが，溶出はシ之として小孔を通して行わ れることが確認された ${ }^{19)}$ ，二の点をさらに詳しく調べる ために，低分子化合物の場合，膜表面に存在する小孔以 外の膜のきれつからの溶出も考えられるので，䣼素を含 むカブセルを用いて，䣼の容出に与える一次乳化浓の 摫拌速度の影響について娭討を加えた。

樭拌速度 500，4000 扰よび $9000 \mathrm{rpm}$ で調製した一 次乳液から得られた 3 種類の含醉素カブセル（100 300 


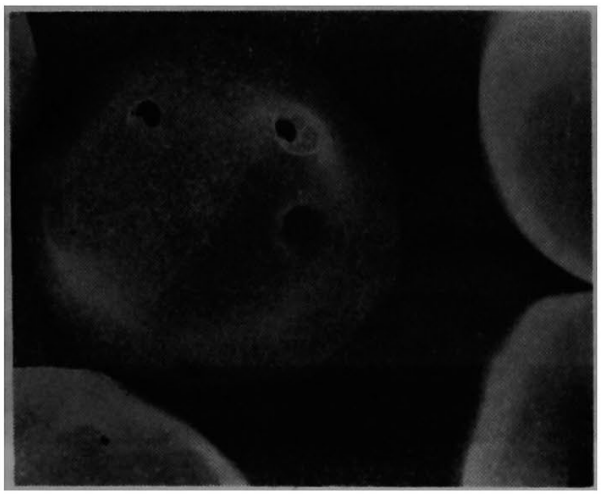

(a)

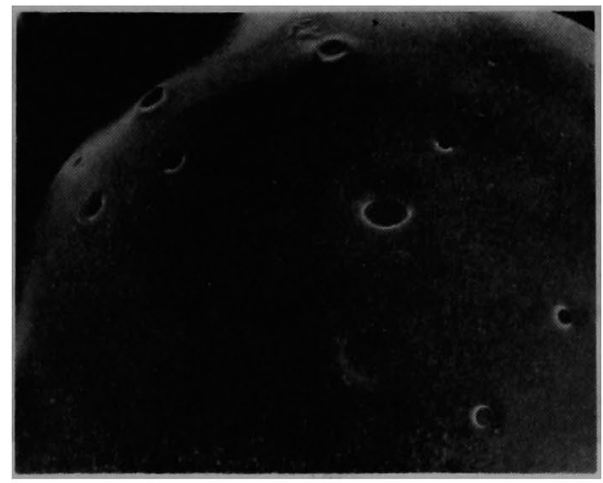

(b)

Fig. 2. Scanning electron micrographs of polystyrene capsules prepared from the emulsions agitated rapidly $(9000 \mathrm{rpm})$ : capsule size (a), $100-300 \mu \mathrm{m}$ diameter ( $\times 300) ;\left(\right.$ b), ${ }^{\mathrm{a})} 300-400 \mu \mathrm{m}$ diameter $(\times 1000)$.

* The picture was quoted from that presented in the 3rd International Symposium on Microencapsulation.

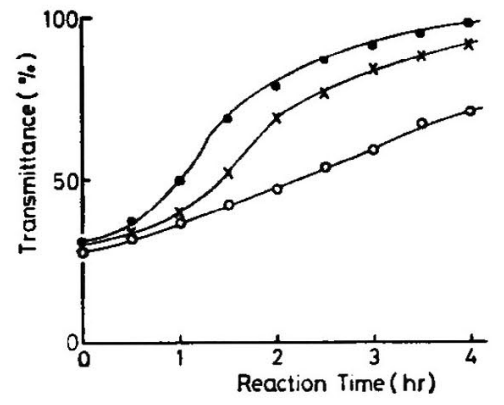

Fig. 3. Transmittance $(700 \mathrm{~nm})$ of starch solution containing capsulated $\alpha$-amylase as a function of time: capsule size, $100-300 \mu \mathrm{m}$ in diameter; stirring rate of primary emulsions, $500 \mathrm{rpm}(O)$, $4000 \mathrm{rpm}(X)$, and $9000 \mathrm{rpm}(\bullet)$.

$\mu \mathrm{m}$ に分級したもの)について，カブセルからの $\alpha-$ ミ ラーゼの溶出をデンプンの分解挙動をむとに検討した。

結果を Fig. 3 飞示した.これより，反応液の $700 \mathrm{~nm}$

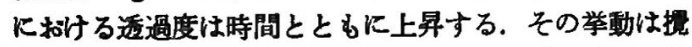
抨速度が大きいカブセルほど高い，これはデンブンの分 解がより著しいことを示すもので，カブセルからの $\alpha$-フ ミラーゼの溶出が高いことを意味している，低速回転の 場合にもある程度の䤃案の溶出が認められた。これは Fig. 1 に示した視野以外に，低い確率で小孔が存在する ことを示している. 一方高速回転の場合, 䣼素の溶出性 は低速回転の場合に比べて必ずしも高くない。これはカ ブセル調製時での高速回転乳化による一部硣素の失活に よるか，溶出測定の直前に行う洗浄の際の醅而の流失に よるためと考えられる. しかしながら，本実験結果はカ
ブセルからの醉索の溶出が小孔を通して行われ、この小 孔の生成が一次乳化液の回転速度に密接に関係している ことを示している.

以上の結果はカプセルからの芯物質溶出を実験的に容 易に制御することができる可能性を示するので，カブセ ルからの芯物質溶出を利用する立場からは興味深い事実 である. カブセルに対しょり高度の機能を期待するため には，溶出に影響を及ぼす小孔の大きさと数を制御する 実験的方法を調べることが要求される. それには小孔の 生成機構についてさらに詳しく検討する必要がある.

\section{2 カプセル膜の小孔形成}

カブセル膜の小孔形成を検討するために，カブセル内 部の状態について光学顕微鏡による䚍察を試みた，それ を Fig. 4, 5 に示した。低速乳化での小粒径カブセルの 場合, 幾つかのカブセルに孔が見られるが，大部分のカ ブセルは透明で良好な均一性をるつカブセル膜を示し た.乙かし粒径が大きいのは, 瞙内部に明らかに泡の 存在が確認された. 一方高速回転乳化の場合, 大小いず れのカブセルにおいても膜に無数の小泡が認められ、こ の小泡の大ささ低速回転乳化により得られたカプセル の泡に比べて小さく, 1 10 $\mu \mathrm{m}$ 程度と概算された。

高速回転での小粒径カブセルを押しつぶして得たカフ セルの顕微鏡写真を Fig. 6 K示した. これよりカブセ ルの破裂部分での膜厚はカブセル粒径に対しかなり薄い と思われる. 膜厚測定は電子䫒微鏡による方法 ${ }^{10)}$ がある が，本実験と同様な方法で得られたカブセルの膜厚は流 動層竞燥法 ${ }^{17}$ を用いる測定方法で 10 20 $\mu \mathrm{m}$ の範囲に あることが知られている13).これより，Fig. 4 6 で見 られるカプセルの外形が球表面を示すことを考虑する と，小泡は膜内に分布しているとみなすことができる. 


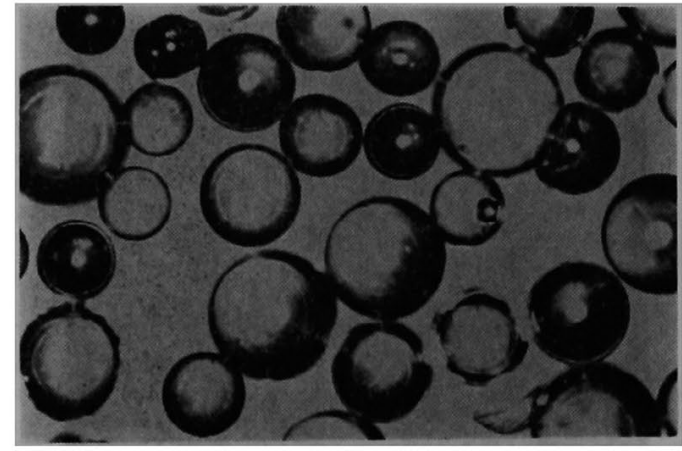

(a)

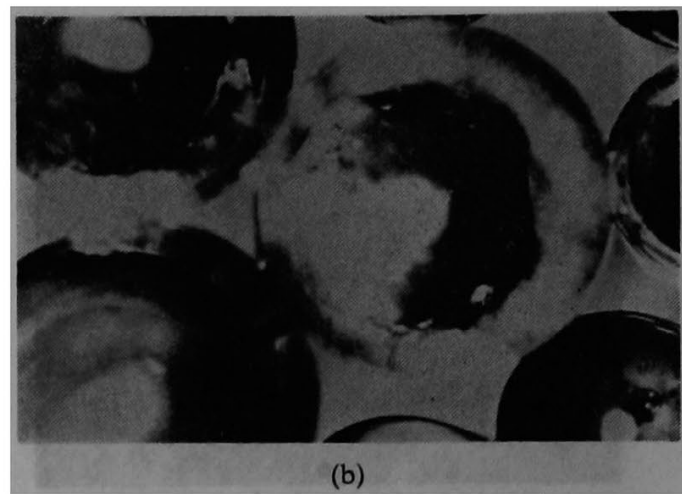

(b)

Fig. 4. Optical micrographs of polystyrene capsules prepared from the emulsions agitated slowly $(500 \mathrm{rpm})$ : capsule size (a), $100-300 \mu \mathrm{m}$ diameter ( $\times 100)$; (b), $300-400 \mu \mathrm{m}$ diameter $(\times 150)$.

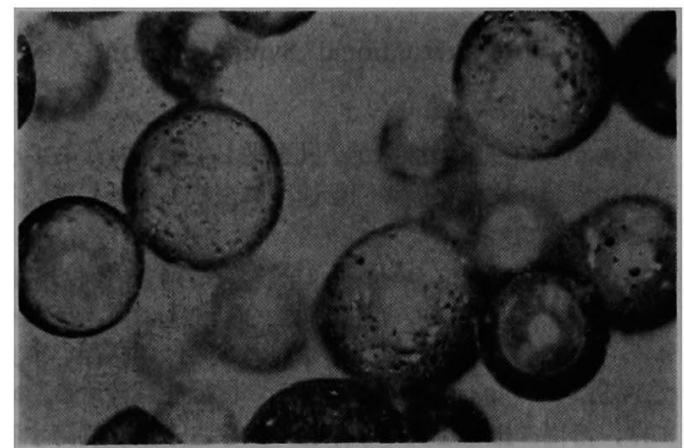

(a)

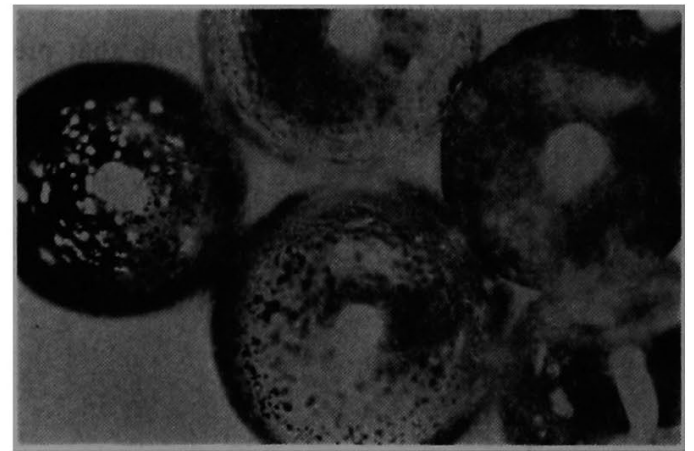

(b)

Fig. 5. Optical micrographs of polystyrene capsules prepared from the emulsions agitated rapidly (9000 rpm): capsule size (a), $100-300 \mu \mathrm{m}$ diameter ( $\times 100)$; (b), 300-400 $\mu \mathrm{m}$ diameter ( $(150)$.

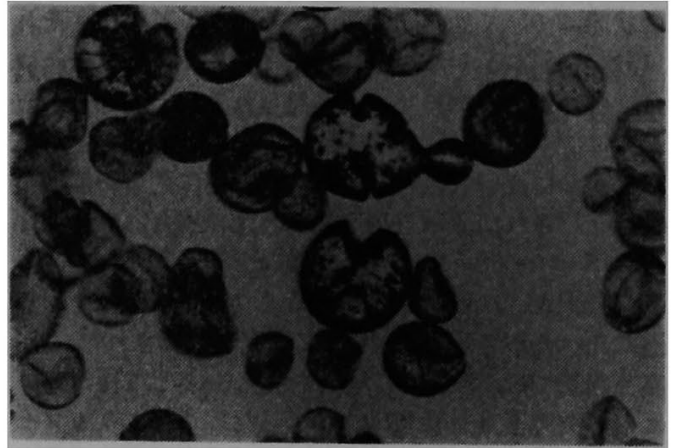

Fig. 6. Optical micrograph of crushed polystyrene capsules $(\times 100)$.

次に一次乳化液の光学䫓微鏡写真を Fig. 7 に示した. 低速回転の場合, $20 \mu \mathrm{m}$ 前後の比較的大きい液滴が見ら れ, 高速回転では数 $\mu \mathrm{m}$ の大きさの微少液滴が観测され た.すなわち，䚌拌速度が高くなる汪ど夜滴恃微細化す
る予想どおりの結果を示した。 これはカブセル膜の小狍 の場合によく類似していることから，実测された小泡仕 一次乳化液滴がそのままカブセル膜内に閉じ込められた 結果生じたものと判断される.

水中乾燥法によって得られた PS カブセルの生成過程 はまず二次乳化条件によって定められた大きさのカフ セルになるまで一次乳化液滴の集合と合一が起こり, 次 に溶剤の蒸発とともに壁膜が硬化し，カブセル化が行わ れると考えられる.ここで, 液滴の粒径が小さい汪ど未 合一のままの液滴が多くなり，それらが結果的にカブセ 儿化の際に膜に取り残されたと解釈される。

光学顕微鏡写真に見られる小泡の分布状態は先に述べ たカブセル膜の小孔のそれによく類似している。この事 実は小泡がカブセル膜の孔形成に奇与していることを示 している.すなわち，小孔の生成は小泡の薄膜部分がカ ブセル化の際に受けた温度などのわずかな調製条件の変 化によって容易に破壞されて生じたものと解积される.

以上の実匰結果より，本実験条件で調製したカブセル 


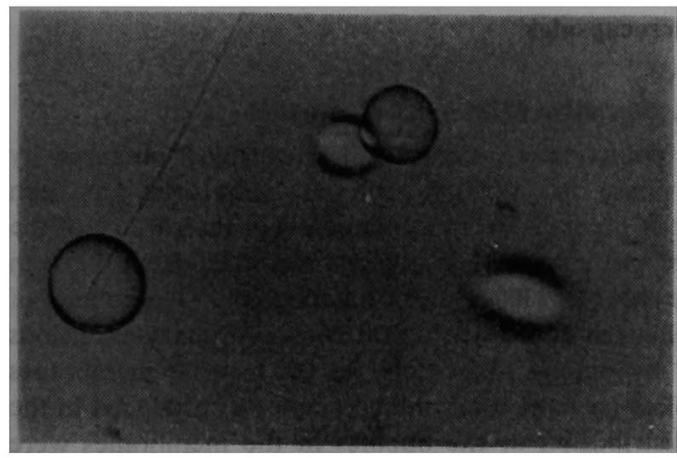

(a)

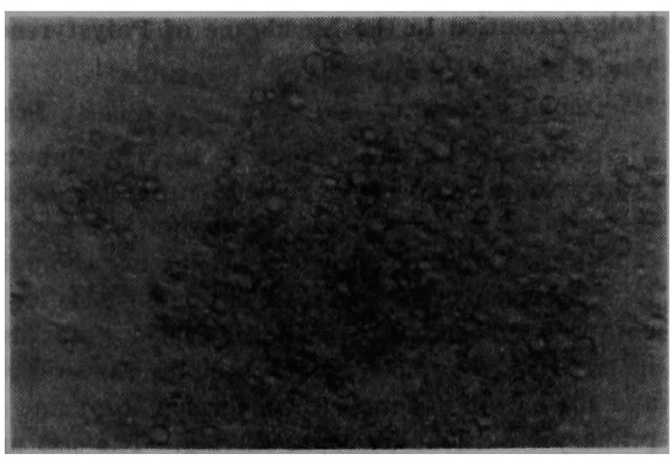

(b)

Fig. 7. Optical micrographs of droplets in $\mathrm{W} / \mathrm{O}$ primary emulsions $(\times 400)$ : agitation rate (a), $500 \mathrm{rpm}$; (b), $9000 \mathrm{rpm}$.

に和いては, 一次乳化液の揮挥速度の增大に上って液中

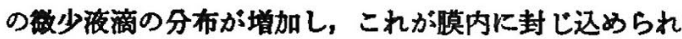
て獏の多孔性を発琾させるものと考えられる。.さらに容 出の大部分はこの膜を通して行われることが明らかにな った.このことは、一次乳化の䁌拌条件でカブセル膜の 小れの生成を制御することができることを意味している が，従来考えられてきたカブセル膜の半透性に関してさ らに詳しい知見を与えるるのと判断される.

小孔生成が秏化条件に直接関保している事実に立脚し て膜の多孔性を考える場合，乳化条件，すなわちここで はゼラチン䈐度について検討を加える必要がある. 本実 乳化液中のぜラチンの量を增すと乳化液が安定化す るため，カブセル粒径は小さくなる傾向を示すこの場 合，カブセルが小さいと洗浄，沪過などの後処理に不便 をきたすことになる. 一方ゼラチンの量を減少させる と, 乳化状態は不安定になってカブセルの粒径分布が広 がり，カブセル取率が低下することになる．これらのこ とから，本研究で用いた実臨条件は収率，粒径などを十 分考虑して設定されたものである.なお，ぜラチン以外 の乳化安定剤の影䈐についてもさらに検討を行う必要が あろう.

\section{4 結 票}

(1) 本研究で得られたボリスチレンカプセルには，走 查電子影改鏡钼察により, 膜に小孔の存在が確喼され た。この小孔嵪速乳化の場合に著しいが, 特に粒径の 大きいカブセルにおいて多く見いだされる.

(2) 高速䚌拌乳化液から調製したカブセルには, 光学 䡛微鏡に上り膜内に小泡が認められた。この小泡は，一 次乳化の擤䢁速度が大きくなるほど微少液滴の分布が高 まり，カブセル化の際に末合一のままで壁膜内に封じ込 められる結果生成したすのと解积される.

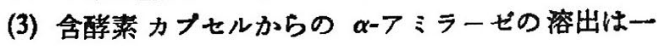

次乳化液の毘拌速度に依存して增加する．溶出がカブセ 儿膜の小孔を通して行われることを考えあわせると，カ ブセル壁膜の多孔性は膜に存在する微少の一次乳化液滴 の破壊によって引き起こされたものと推察される.

\section{文触}

1) “マイクロカプセル特集号”，工䇬材料，17，7 月号 (1969).

2) “特菓マイクロカプセル”, 化学と工業, 22, 10 月号 (1969).

3）近藤朝二, “マイクロカプセル”、日刊工業新䦎 社 (1970).

4) T.M.S. Chang, F.C. McIntosh, S.G. Mason, Canad. J. Physiol. Pharmacol., 44, 115(1966).

5) T. M. S. Chang, M. J. Poznansky, Nature, 218, 234 (1969).

6) T.M.S. Chang, Science, 146, 524 (1969).

7) Y. Shigeri, T. Kondo, Chem. Pharm. Bull., 17, 1073 (1969).

8) 後藤 茂, 中岛海子, 鹤田実, 佐藤 久, 中 山太二, 薬剤学, 34, 160 (1974).

9) S. Suzuki, T. Kondo, S. G. Mason, Chem. Pharm. Bull., 16, 1629 (1968).

10) M. Koishi, N. Fukuhara, T. Kondo, Chem. Pharm. Bull., 17, 804 (1969).

11) 北島昌夫, 官野静夫, 近藤朝二, 工業化学雑誌, 72, 493 (1969).

12）野沢墥夫，八木利夫，東出福司，薬剂学， 35， 81 (1975).

13）野沢靖夫，牛川 務，米沢泰三，東出福司，薬 绪学, 36, 7 (1976).

14) Y. Nozawa, F. Higashide, T. Kanamoto, J. Appl. Polym. Sci., 20, 3197 (1976).

15) H. Fuwa, J. Biochem., 41, 583 (1957).

16）官野静夫，近藤朝二，工業化学雅誌，73，1755 (1970).

17) 東出福司, 牛川 務, 薬剂学, 34 (1974). 
Hole Formation in the Membrane of Polystyrene Microcapsules

Yasuo Nozawa*1 and Fukuji Higashide*1

"'Shizuoka College of Pharmacy (2-1, Oshika 2-chome, Shizuoka 422)

Formation of small holes in the membrane of polystyrene microcapsules (capsules) prepared by evaporating the organic solvent from the organic phase in (W/O)/W complex emulsions has been investigated by microscopic observation. The number of holes $(1-10 \mu \mathrm{m}$ in diameter) in the surface of the capsules apparently increased as the agitation rate of primary $W / O$ emulsions increased from $500 \mathrm{rpm}$ to $9000 \mathrm{rpm}$ and the increase was remarkable for large capsules $(300-400 \mu \mathrm{m}$ in diameter). The release of encapsulated $\alpha$-amylase from the capsules was also enhanced as the stirring rate of the primary emulsions increased. A number of fine bubbles were observed by optical microscopy in the capsule membranes and they were assumed to be formed from fine droplets (several micrometer diameter) produced in the primary emulsions by rapid stirring. The size and distribution of the bubbles in the membranes were similar to those of the holes in the surface of the capsules. Therefore, the holes in the capsule membranes were presumably formed at thin film parts which were around the droplets and were easily breaked by a slight change in experimental condition such as temperature in the microencapsulation process.

KEY WORDS Polystyrene / Microcapsule / Hole Formation / $\alpha$-Amylase / Scanning Electron Microscopy / Microencapsulation / W/O Primary Emulsion / (W/O)/W Complex Emulsion / Capsule Membrane / Release /

(Received April 30, 1977: Accepted July 15, 1977)

[Kobunshi Ronbunshu, 34(11), 757-762 (1977)] 